\title{
Pengaruh Perputaran Kas, Perputaran Piutang Dan Perputaran Modal Kerja Terhadap Rentabilitas Pada PT Wijaya Karya
}

\author{
Edy Firmansyah ${ }^{1}$, Anto Tulim ${ }^{2}$, Dina Hastalona ${ }^{3}$, Desliani Zalukhu ${ }^{4}$ \\ ${ }^{1}$ Dosen Tetap S-1 Akuntansi, Sekolah Tinggi IImu Ekonomi ITMI Medan, Jl. Timah Putih Blok G. \\ 15-17 Komplek Asia Mega Mas Medan 20224 Telp. (061) 7356888 \\ 2Dosen Tetap S-1 Manajemen, Sekolah Tinggi Ilmu Ekonomi ITMI Medan, JI. Timah Putih Blok \\ G. 15-17 Komplek Asia Mega Mas Medan 20224 Telp. (061) 7356888 \\ ${ }^{3}$ Dosen Tetap S-1 Manajemen, Sekolah Tinggi Ilmu Ekonomi ITMI Medan, JI. Timah Putih Blok \\ G. 15-17 Komplek Asia Mega Mas Medan 20224 Telp. (061) 7356888 \\ ${ }^{4}$ Mahasiswi S-1 Akuntansi, Sekolah Tinggi Ilmu Ekonomi ITMI Medan, Jl. Timah Putih Blok G. \\ 15-17 Komplek Asia Mega Mas Medan 20224 Telp. (061) 7356888 \\ Email : ${ }^{1}$ efirmansyah58@yahoo.com, 2antotulim@yahoo.com, \\ 33dinahastalona.mardani@gmail.com ${ }^{4}$ deslianizalukhu@gmail.com
}

\begin{abstract}
Economic rentability is the achievement achieved by a company expressed in percentage terms, after being compared between the results obtained with the capital used. In addition to increasing economic rentability, there are still other factors that are no less important to pay attention to companies in assessing the level of efficiency of the company, among others, judging from the rate of cash turnover, receivable turnover and working capital turnover. This research aims to find out the effect of cash turnover, receivable turnover and working capital turnover on economic rentability both partially and simultaneously on PT. Wijaya Karya (Persero) Tbk. The research method used by researchers is descriptive quantitative by using data from financial statements of PT. Wijaya Karya (Persero) Tbk. Based on the results of research conducted it can be known that partially variable cash turnover and working capital turnover do not have a significant effect on economic rentability, and partial receivable turnover has a significant effect on economic rentability. Simultaneously variable cash turnover, receivable turnover and working capital turnover have a significant effect on economic rentability.
\end{abstract}

Keywords: Cash Turnover, Receivable Turnover, Working Capital Turnover, Economic Rentability.

\begin{abstract}
ABSTRAK
Rentabilitas ekonomi merupakan prestasi yang dicapai perusahaan yang dinyatakan dalam persentase, setelah dibandingkan antara hasil yang diperoleh dengan modal yang digunakan. Selain meningkatkan rentabilitas ekonomi, masih ada faktor lain yang tidak kalah penting untuk diperhatikan perusahaan dalam menilai tingkat efisiensi perusahaan antara lain dilihat dari tingkat perputaran kas, perputaran piutang dan perputaran modal kerja. Penelitian ini bertujuan untuk mengetahui pengaruh perputaran kas, perputaran piutang dan perputaran modal kerja terhadap rentabilitas ekonomi baik secara parsial maupun simultan pada PT. Wijaya Karya (Persero) Tbk. Metode penelitian yang digunakan oleh peneliti adalah deskriptif kuantitatif dengan menggunakan data dari Laporan Keuangan PT. Wijaya Karya (Persero) Tbk. Berdasarkan hasil penelitian yang dilakukan dapat diketahui bahwa secara parsial variabel perputaran kas dan perputaran modal kerja tidak berpengaruh signifikan terhadap rentabilitas ekonomi, dan perputaran piutang secara parsial berpengaruh signifikan terhadap rentabilitas ekonomi. Secara simultan variabel perputaran kas, perputaran piutang dan perputaran modal kerja berpengaruh signifikan terhadap rentabilitas ekonomi.
\end{abstract}

Kata Kunci: Perputaran Kas, Perputaran Piutang, Perputaran Modal Kerja, Rentabilitas Ekonomi. 


\section{PENDAHULUAN}

\subsection{Latar Belakang Masalah}

Sektor konstruksi merupakan pendorong pertumbuhan ekonomi di Indonesia. Konstruksi memegang peranan penting dalam perekonomian negara, dan menjadi salah satu penyokong pertumbuhan ekonomi nasional. Pemerintah Indonesia memiliki visi dan misi memajukan perekonomian Indonesia melalui berbagai macam program kerja salah satunya yaitu melalui pembangunan infrastruktur di kota maupun di desa karena tanpa infrastruktur yang memadai, pertumbuhan ekonomi akan lambat. Perputaran kas PT. Wijaya Karya (Persero) Tbk yang merupakan salah satu perusahaan di sector konstruksi. dari tahun 2010 sampai 2018 fluktuatif. Perputaran kas tertinggi yaitu pada tahun 2013 sebesar 10,46 kali sedangkan terendah tahun 2018 yaitu sebesar 2,76 kali. Perputaran piutang pada PT. Wijaya Karya (Persero) Tbk. dari tahun 2010 sampai dengan 2018 cenderung fluktuatif. Perputaran piutang tertinggi pada tahun 2013 sebesar 5,63 kali, sedangkan perputaran piutang terendah yaitu pada tahun 2018 sebesar 3,86 kali. Perputaran modal kerja juga cenderung fluktuatif. Pada tahun 2010 perputaran modal kerja sebesar 4,06 kali, pada tahun 2011 meningkat menjadi 10,87 kali. Pada tahun 2012 kembali meningkat menjadi 14,89 kali dan meningkat lagi pada tahun 2013 menjadi 17,08 kali, pada tahun 2014 turun menjadi 12,00 kali. Demikian pada tahun berikutnya terus menurun menjadi 6,93 kali pada tahun 2015, pada tahun 2016 kembali menurun menjadi 2,25 kali. Mengalami peningkatan pada tahun 2017 menjadi 2,92 kali dan pada akhir periode tahun 2018 perputaran modal kerja meningkat dari tahun sebelumnya menjadi 3,60 kali. Berdasarkan data diatas, dapat dilihat juga bahwa rentabilitas ekonomi PT. Wijaya Karya (Persero) Tbk. juga cenderung fluktuatif. Rentabilitas ekonomi tertinggi terlihat pada tahun 2013 yaitu sebesar 9,65\% sedangkan rentabilitas ekonomi terendah terlihat pada tahun 2018 yaitu sebesar $5,65 \%$.

\subsection{Tujuan Penelitian}

1. Untuk mengetahui pengaruh perputaran kas terhadap rentabilitas di PT Wijaya Karya

2. Untuk mengetahui pengaruh perputaran piutang terhadap rentabilitas di PT Wijaya Karya

3. Untuk mengetahui pengaruh perputaran modal kerja terhadap rentabilitas di PT Wijaya Karya

4. Untuk mengetahui pengaruh perputaran kas, perputaran piutang dan perputaran modal kerja terhadap rentabilitas di PT Wijaya Karya

\subsection{Literatur (Tinjauan Pustaka)}

Kas

"Kas adalah aktiva paling likuid yang mencakup mata uang, deposito, dan cek" [1]. "kas merupakan uang tunai yang dimiliki perusahaan dan dapat segera digunakan setiap saat" [2]. Berdasarkan pengertian diatas, dapat disimpulkan bahwa kas adalah harta yang sifatnya paling likuid, karena dapat digunakan untuk membayar kewajiban perusahaan.

"rasio perputaran kas (cash turnover) bermanfaat untuk mengukur tingkat kecukupan modal kerja perusahaan yang dibutuhkan untuk membayar tagihan dan membiayai penjualan" [3].

"Rasio perputaran kas (cash turnover) dapat dihitung dengan rumus :

Cash Turnover $=$ Penjualan / Rerata Kas [4].

\section{Piutang}

"Piutang yang dimiliki oleh suatu perusahaan mempunyai hubungan erat dengan volume penjualan kredit" [1]. Berdasarkan pengertian diatas, dapat kita ambil kesimpulan bahwa piutang merupakan hak untuk menagih sejumlah uang dari si penjual kepada si pembeli yang timbul karena adanya suatu transaksi. Piutang timbul apabila seseorang atau perusahaan menjual barang atau jasa kepada orang lain atau perusahaan lain secara kredit.

"Perputaran piutang merupakan rasio yang digunakan untuk mengukur berapa lama penagihan piutang selama satu periode atau berapa kali dana yang ditanam dalam piutang ini berputar dalam satu periode.Tingkat perputaran piutang dapat diketahui dengan membagi jumlah penjualan kredit selama periode tertentu dengan jumlah rata - rata piutang. Rumus untuk mencari perputaran piutang :

Perputaran Piutang $=$ Penjualan $/$ Rata-Rata Piutang [5] 


\section{Modal Kerja}

"Antara penjualan dengan modal kerja terdapat hubungan yang erat. Apabila volume penjualan naik investasi dalam persediaan dan piutang juga meningkat, ini berarti juga meningkatkan modal kerja" [6].

"Untuk menilai keefektifan modal kerja dapat digunakan rasio antara total penjualan dengan jumlah modal kerja rata-rata tersebut (working capital turn over)". Dari pernyataan diatas dapat disimpulkan bahwa perputaran modal kerja menunjukkan seberapa besar perusahaan mampu memanfaatkan modal kerja untuk menghasilkan penjualan bersih. Perputaran modal kerja menunjukkan seberapa besar modal kerja berputar dalam satu tahun. Rumus yang digunakan untuk mencari perputaran modal kerja adalah :

Perputaran Modal Kerja = Penjualan / Modal Kerja [7].

\section{Rentabilitas}

"Untuk mengukur tingkat keuntungan suatu perusahaan, digunakan rasio keuntungan atau rasio profitabilitas yang dikenal juga dengan nama rasio rentabilitas. Rasio profitabilitas merupakan rasio untuk menilai kemampuan perusahaan dalam mencari keuntungan" [8].

"Rasio profitabilitas atau rasio rentabilitas dibagi dua yaitu sebagai berikut:

1. Rentabilitas Ekonomi, yaitu dengan membandingkan laba usaha dengan seluruh modal (modal sendiri dan asing).

2. Rentabilitas Usaha (sendiri), yaitu dengan membandingkan laba yang disediakan untuk pemilik dengan modal sendiri. Adapun rumus dari rentabilitas seperti yang sudah dijelaskan di atas adalah sebagai berikut :

Rentabilitas Ekonomi = Laba Usaha $/$ Modal Asing + Modal Sendiri X 100\%

Rentabilitas Usaha Sendiri = Laba Bersih / Modal Sendiri X 100\%" [9]

\section{METODE PENELITIAN}

\subsection{Objek Penelitian}

Subjek penelitian yang peneliti lakukan adalah PT. Wijaya Karya (Persero) Tbk. pada periode tahun 2010 sampai dengan periode tahun 2018. Objek penelitian dalam penelitian ini adalah laporan keuangan PT. Wijaya Karya (Persero) Tbk. pada periode tahun 2010 sampai dengan periode tahun 2018.

\subsection{Tempat dan Waktu}

Penelitian ini dilakukan pada perusahaan PT. Wijaya Karya (Persero) Tbk. (WIKA) yang terdaftar di Bursa Efek Indonesia. Waktu penelitian dilaksanakan dari bulan April sampai dengan bulan September tahun 2019.

\subsection{Populasi dan Sampel}

"Populasi adalah wilayah generalisasi yang terdiri atas obyek/subyek yang mempunyai kualitas dan karakteristik tertentu yang ditetapkan oleh peneliti untuk dipelajari dan kemudian ditarik kesimpulannya" [10]. Populasi yang digunakan dalam penelitian adalah Laporan Keuangan PT. Wijaya Karya (Persero) Tbk. yang terdaftar di Bursa Efek Indonesia (BEI) berdasarkan data dari www.idx.co.id pada periode tahun 2010-2018.

"Sampel adalah bagian dari jumlah dan karakteristik yang dimiliki oleh populasi tersebut" [11]. Sampel yang digunakan dalam penelitian ini adalah laporan keuangan PT. Wijaya Karya (Persero) Tbk. tahun 2010-2018 (Per kuartal, 4 × $9=36$ ).

\subsection{Teknik Pengumpulan Data}

Jenis data yang digunakan dalam penelitian ini adalah kuantitatif, karena berbentuk data angka. Sumber data yang digunakan dalam penelitian ini merupakan data sekunder yaitu data yang diperoleh lewat dokumen berupa laporan keuangan PT. Wijaya Karya (Persero) Tbk. yang diperoleh dari www.idx.co.id.

\subsection{Uji Kualitas Data Uji Asumsi Klasik}

Tujuan pengujian ini adalah untuk memberikan kepastian bahwa persamaan regresi yang didapatkan memiliki ketepatan dalam estimasi, tidak bias dan konsisten. Dalam penelitian ini pengujian yang dapat dilakukan dalam uji asumsi klasik ini adalah uji normalitas, uji autokorelasi, uji heteroskedatisitas, uji multikolonieritas. 


\section{Uji Normalitas}

"Uji normalitas bertujuan untuk menguji apakah dalam model regresi, variabel pengganggu atau residual memiliki distribusi normal" [12]. Pengujian ini dilakukan untuk menguji apakah dalam sebuah model regresi, variabel independen, variabel dependen, atau keduanya mempunyai distribusi normal atau tidak. Model regresi yang baik adalah yang memiliki distribusi data normal atau mendekati normal.

\section{Uji Outokorelasi}

"Uji autokorelasi bertujuan menguji apakah model regresi linear ada korelasi antara kesalahan pengganggu pada periode $t$ dengan kesalahan pengganggu pada periode $t-1$ (sebelumnya)" [12]. Jika terjadi korelasi, maka dinamakan ada problem autokorelasi. Masalah autokorelasi relatif jarang terjadi karena gangguan pada observasi yang berbeda berasal dari individu kelompok yang berbeda. Model regresi yang baik adalah regresi yang bebas dari autokorelasi.

\section{Uji Heteroskedastisitas}

"Uji Heteroskedastisitas bertujuan menguji apakah dalam model regresi terjadi ketidaksamaan varians dari residual satu pengamatan ke pengamatan yang lain. Jika varians dari residual satu pengamatan ke pengamatan yang lain tetap, maka disebut homoskedastisitas dan jika berbeda disebut heteroskedastisitas" [13].

\section{Uji Multikolinearitas}

Menurut "Uji multikolonieritas bertujuan untuk menguji apakah model regresi ditemukan adanya korelasi antar variabel bebas (independen)". Model regresi yang baik adalah tidak terjadi korelasi diantara variabel bebas. Jika yang terjadi adalah sebaliknya yaitu variabel bebas saling berkorelasi, maka variabel-variabel ini tidak ortogonal.

Uji Hipotesis

Peneliti menggunakan teknik analisis data sebagai berikut :

1. Analisis Regresi Linear Berganda

2. Uji F

3. Uji-t

4. Koefisien determinasi $\left(R^{2}\right)$

\section{HASIL PENELITIAN DAN PEMBAHASAN}

\subsection{Hasil Penelitian \\ Uji Asumsi Klasik \\ Uji Normalitas}

Untuk mendeteksi apakah residual berdistribusi normal atau tidak, ditunjukkan dengan analisis grafik histogram dan grafik Normal Probability Plotseperti Gambar di bawah ini : 


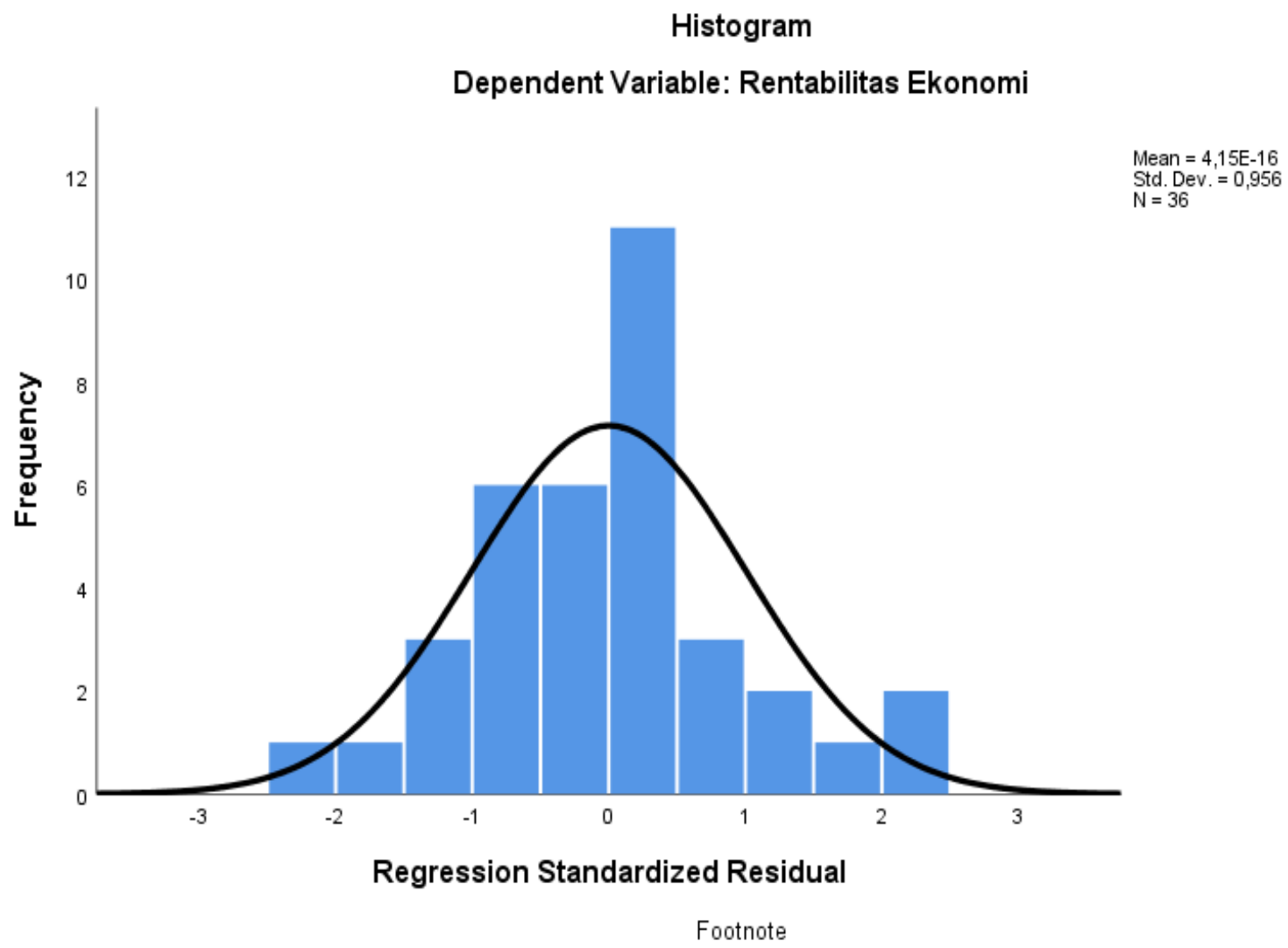

Sumber : Hasil Penelitian, 2019 (Data Diolah)

Gambar 1. Grafik Histogram Uji Normalitas Data

Grafik histogram diatas menunjukkan bahwa pendistribusian data terjadi secara normal. Hal ini dapat dilihat dari bentuk garis yang tidak melenceng ke kanan maupun ke kiri.

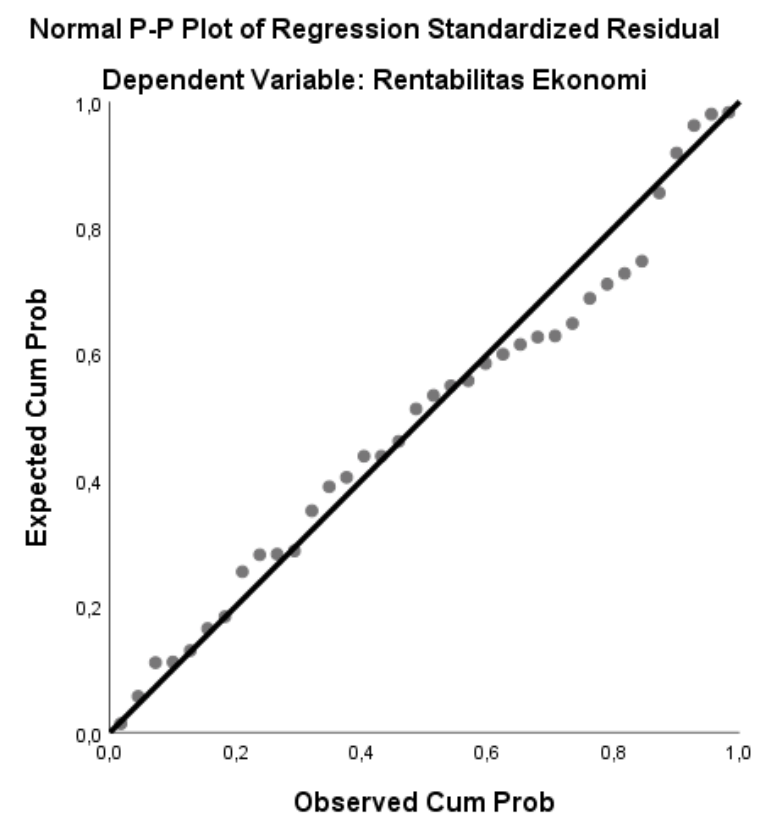

Sumber : Hasil Penelitian, 2019 (Data Diolah)

Gambar 2. Grafik P-Plot Normalitas 
Gambar grafik hasil $P-P$ Plot diatas menunjukkan peyebaran titik-titik disekitar garis diagonal, hal ini menunjukkan bahwa data telah berdistribusi secara normal.

\section{Uji Outokorelasi}

Uji autokorelasi bertujuan untuk menguji apakah model regresi linear ada korelasi antara kesalahan pengganggu pada periode $t$ dengan kesalahan pengganggu pada periode $t-1$ (sebelumnya). Uji autokorelasi pada penelitian ini dilakukan dengan melihat nilai statistik Durbin Watson dengan tingkat kepercayaan 5\% $(0,05)$. Berikut adalah tabel hasil uji Durbin Watson :

Hasil uji Durbin Watson seperti pada Tabel di bawah ini :

\section{Tabel 1 Uji Outokorelasi}

Model Summary

\begin{tabular}{|c|c|c|c|c|c|}
\hline \multirow[b]{2}{*}{ Model } & \multirow[b]{2}{*}{$\mathrm{R}$} & & \multirow[b]{2}{*}{ Durbin-Watson } \\
\hline & & R Square & $\begin{array}{l}\text { Adjusted R } \\
\text { Square }\end{array}$ & $\begin{array}{l}\text { Std. Error of } \\
\text { the Estimate }\end{array}$ & \\
\hline 1 &, $977^{\mathrm{a}}$ & ,955 & ,951 & ,53957 & 1,913 \\
\hline
\end{tabular}

Berdasarkan tabel 4.2 diatas diketahui bahwa nilai DW sebesar 1,913. Berdasarkan tabel DW untuk sampel (n) 36 dan variabel independen (k) 3 maka diperoleh nilai dL (batas bawah) = 1,2953 dan dU (batas atas) = 1,6539. Angka DW sebesar 1,913 lebih besar dari batas atas (dU) 1,6539 dan kurang dari $4-1,6539(4-\mathrm{dU})$, maka dapat disimpulkan tidak terdapat autokorelasi.

\section{Uji Multikolinearitas}

Hasil uji multikolinearitas seperti pada Tabel di bawah ini :

\section{Tabel 2 Uji Multikolinearitas}

\begin{tabular}{|c|c|c|c|c|c|c|c|}
\hline \multirow[b]{3}{*}{ Model } & \multicolumn{5}{|c|}{ Coefficients $^{a}$} & & \\
\hline & \multicolumn{2}{|c|}{$\begin{array}{l}\text { Unstandardized } \\
\text { Coefficients }\end{array}$} & \multirow{2}{*}{$\begin{array}{c}\text { Standardized } \\
\text { Coefficients } \\
\text { Beta } \\
\end{array}$} & \multirow[b]{2}{*}{$\mathrm{t}$} & \multirow[b]{2}{*}{ Sig. } & \multicolumn{2}{|c|}{$\begin{array}{l}\text { Collinearity } \\
\text { Statistics }\end{array}$} \\
\hline & B & Std. Error & & & & Tolerance & VIF \\
\hline 1 (Constant) &,- 423 & ,204 & & $-2,074$ &, 046 & & \\
\hline Perputaran Kas & ,121 &, 064 & ,131 & 1,890 & ,068 & ,291 & 3,439 \\
\hline $\begin{array}{l}\text { Perputaran } \\
\text { Piutang }\end{array}$ & 1,478 & 105 & ,845 & 14,072 &, 000 & ,387 & 2,584 \\
\hline $\begin{array}{l}\text { Perputaran } \\
\text { Modal Kerja }\end{array}$ & ,024 & ,033 & ,041 & ,726 & ,473 & ,447 & 2,236 \\
\hline
\end{tabular}

a. Dependent Variable: Rentabilitas Ekonomi

Sumber : Hasil Penelitian, 2019 (Data Diolah)

Berdasarkan hasil output pada tabel diatas dapat diketahui bahwa nilai Toleransi untuk variabel perputaran kas 0,291 , variabel perputaran piutang 0,387 , variabel perputaran modal kerja 0,447 yakni lebih besar dari 0,10 dapat disimpulkan bahwa tidak terjadi multikolinearitas. Nilai VIF yang diperoleh untuk variabel perputaran kas 3,439 , variabel perputaran piutang 2,584 , dan variabel perputaran modal kerja 2,236, nilai VIF dari ketiga variabel diatas lebih kecil dari 10, maka dapat disimpulkan tidak terjadi multikolinearitas dalam model regresi tersebut.

\section{Heterokedastisitas} bawah ini :

Hasil pengujian heterokedastisitas dengan grafik Scatterplot seperti pada Gambar di 


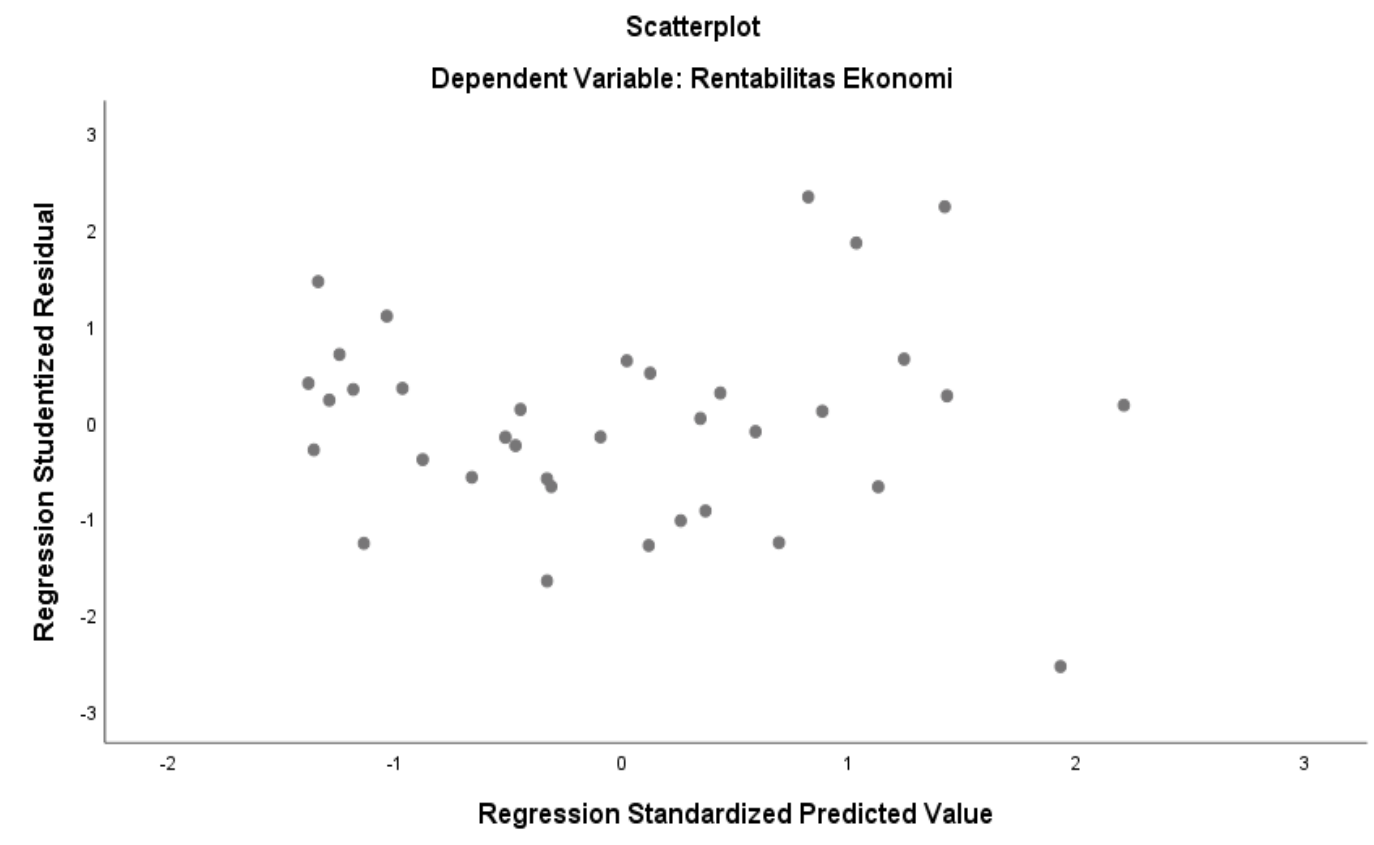

Sumber : Hasil Penelitian, 2019 (Data Diolah)

Gambar 3. Grafik Uji Heterokedastisitas

Dari Gambar 3. terlihat bahwa titik-titik menyebar di atas dan di bawah angka 0 pada sumbu Y. Dengan demikian, dapat disimpulkan persamaan regresi hipotesis ini terbebas dari asumsi heterokedastisitas.

\section{Pengujian Hipotesis}

\section{Hasil Uji Koefisien Regresi Linear Berganda}

Hasil analisis regresi linear berganda seperti pada Tabel di bawah ini :

Tabel 4 Analisis Regresi Linear Berganda

\begin{tabular}{|c|c|c|c|c|c|c|c|}
\hline \multirow[b]{3}{*}{ Model } & \multicolumn{5}{|c|}{ Coefficients $^{\mathrm{a}}$} & & \\
\hline & \multicolumn{2}{|c|}{$\begin{array}{l}\text { Unstandardized } \\
\text { Coefficients }\end{array}$} & \multirow{2}{*}{$\begin{array}{c}\text { Standardized } \\
\text { Coefficients } \\
\text { Beta }\end{array}$} & \multirow[b]{2}{*}{$\mathrm{t}$} & \multirow[b]{2}{*}{ Sig. } & \multicolumn{2}{|c|}{$\begin{array}{l}\text { Collinearity } \\
\text { Statistics }\end{array}$} \\
\hline & $\mathrm{B}$ & Std. Error & & & & Tolerance & VIF \\
\hline 1 (Constant) &,- 423 & ,204 & & $-2,074$ &, 046 & & \\
\hline Perputaran Kas & ,121 & ,064 & ,131 & 1,890 & ,068 & 291 & 3,439 \\
\hline $\begin{array}{l}\text { Perputaran } \\
\text { Piutang }\end{array}$ & 1,478 & ,105 & ,845 & 14,072 &, 000 & ,387 & 2,584 \\
\hline $\begin{array}{l}\text { Perputaran } \\
\text { Modal Kerja }\end{array}$ & ,024 & ,033 &, 041 & ,726 & ,473 & ,447 & 2,236 \\
\hline
\end{tabular}

a. Dependent Variable: Rentabilitas Ekonomi

Sumber : Hasil Penelitian, 2019 (Data Diolah)

Persamaan regresi linear berganda yang diperoleh yaitu :

$$
Y=-0,423+0,121 X_{1}+1,478 X_{2}+0,024 X_{3}+e
$$

1. Makna dari persamaan regresi linier berganda diatas adalah konstanta sebesar 0,423 , menyatakan bahwa jika perputaran kas, perputaran piutang, dan perputaran modal kerja dianggap konstan, maka rentabilitas ekonomi sama dengan -0,423. 
2. Koefisien regresi perputaran kas sebesar 0,121 kali dan bernilai positif menyatakan bahwa setiap kenaikan perputaran kas akan menyebabkan kenaikan rentabilitas ekonomi sebesar 0,121.

3. Koefisien regresi perputaran piutang sebesar 1,478 kali dan bernilai positif menyatakan bahwa setiap kenaikan perputaran piutang akan menyebabkan kenaikan rentabilitas ekonomi sebesar 1,478.

4. Koefisien regresi perputaran modal kerja sebesar 0,024 kali dan bernilai positif menyatakan bahwa setiap kenaikan perputaran modal kerja akan menyebabkan kenaikan rentabilitas ekonomi sebesar 0,024.

\section{Uji-t (Parsial)}

Hasil uji-t seperti pada Tabel di bawah ini :

\section{Tabel 4 Tabel Uji t}

\section{Coefficients $^{\mathrm{a}}$}

\begin{tabular}{|c|c|c|c|c|c|}
\hline \multirow[b]{3}{*}{ Model } & \multicolumn{4}{|c|}{ 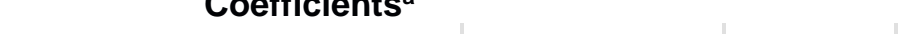 } & \multirow[b]{3}{*}{ Sig. } \\
\hline & \multicolumn{2}{|c|}{ Unstandardized Coefficients } & $\begin{array}{l}\text { Standardized } \\
\text { Coefficients }\end{array}$ & & \\
\hline & $\mathrm{B}$ & Std. Error & Beta & $t$ & \\
\hline 1 (Constant) &,- 423 & ,204 & & $-2,074$ & ,046 \\
\hline Perputaran Kas & ,121 & ,064 &, 131 & 1,890 & ,068 \\
\hline Perputaran Piutang & 1,478 & ,105 & ,845 & 14,072 &, 000 \\
\hline Perputaran Modal Kerja &, 024 &, 033 &, 041 &, 726 & ,473 \\
\hline
\end{tabular}

a. Dependent Variable: Rentabilitas Ekonomi

Sumber : Hasil Penelitian, 2019 (Data Diolah)

Berdasarkan hasil pengujian secara parsial pada tabel 4.5 diatas, dapat dilihat bahwa :

1. Variabel perputaran kas mempunyai nilai thitung sebesar 1,890 sedangkan tabel adalah sebesar 2,03452 sehingga dapat disimpulkan bahwa thitung $<$ tabel yaitu 1,890<2,03452 sehingga keputusannya $\mathrm{H}_{0}$ diterima dan $\mathrm{H}_{a}$ ditolak, artinya variabel perputaran kas secara parsial tidak berpengaruh signifikan terhadap rentabilitas ekonomi pada PT. Wijaya Karya (Persero) Tbk.

2. Variabel perputaran piutang mempunyai nilai thitung sebesar 14,072 sedangkan tabel adalah sebesar 2,03452 sehingga dapat disimpulkan bahwa thitung $>$ tabel yaitu 14,072 > 2,03452 sehingga keputusannya $\mathrm{H}_{0}$ ditolak dan $\mathrm{H}_{\mathrm{a}}$ diterima artinya variabel perputaran piutang secara parsial berpengaruh signifikan terhadap rentabilitas ekonomi pada PT. Wijaya Karya (Persero) Tbk.

3. Variabel perputaran modal kerja mempunyai nilai thitung sebesar 0,726 sedangkan tabel adalah sebesar 2,03452 sehingga dapat disimpulkan bahwa thitung $<$ tabel yaitu 0,726 < 2,03452 sehingga keputusannya $\mathrm{H}_{0}$ diterima dan $\mathrm{H}_{a}$ ditolak, artinya variabel perputaran modal kerja secara parsial tidak berpengaruh signifikan terhadap rentabilitas ekonomi pada PT. Wijaya Karya (Persero) Tbk.

\section{Uji F (Serempak)}

Hasil uji F dapat dilihat pada Tabel di bawah ini :

\section{Tabel 5 Tabel Uji F}

\begin{tabular}{|c|c|c|c|c|c|c|}
\hline \multicolumn{7}{|c|}{ ANOVA $^{a}$} \\
\hline \multicolumn{2}{|l|}{ Model } & $\begin{array}{l}\text { Sum of } \\
\text { Squares }\end{array}$ & $\mathrm{df}$ & Mean Square & $\mathrm{F}$ & Sig. \\
\hline \multirow[t]{3}{*}{1} & Regression & 199,441 & 3 & 66,480 & 228,352 &, 000 \\
\hline & Residual & 9,316 & 32 & ,291 & & \\
\hline & Total & 208,757 & 35 & & & \\
\hline
\end{tabular}

a. Dependent Variable: Rentabilitas Ekonomi

b. Predictors: (Constant), Perputaran Modal Kerja, Perputaran Piutang, Perputaran Kas 
Sumber : Hasil Penelitian, 2019 (Data Diolah)

Berdasarkan uji ANOVA diatas, diperoleh nilai $F_{\text {hitung }}$ sebesar 228,352 sedangkan $F_{\text {tabel }}$ sebesar 2,90 $(228,352>2,90)$. Hal ini berarti bahwa perputaran kas, perputaran piutang, perputaran modal kerja secara simultan berpengaruh signifikan terhadap rentabilitas ekonomi.

\section{Uji Koefisien Determinasi $\left(\mathbf{R}^{2}\right)$}

Hasil uji koefisien determinasi seperti pada Tabel di bawah ini :

\section{Tabel 6 Tabel Koefisien Determinasi $\left(\mathbf{R}^{2}\right)$}

\begin{tabular}{ll|r|r|r} 
& & \multicolumn{2}{c}{ Model Summary } \\
Model & $R$ & R Square & \multicolumn{1}{c}{$\begin{array}{c}\text { Adjusted R } \\
\text { Square }\end{array}$} & $\begin{array}{c}\text { Std. Error of } \\
\text { the Estimate }\end{array}$ \\
\hline 1 &, $977^{\mathrm{a}}$ &, 955 &, 951 &, 53957 \\
\hline
\end{tabular}

a. Predictors: (Constant), Perputaran Modal Kerja, Perputaran

Piutang, Perputaran Kas

Sumber : Hasil Penelitian, 2019 (Data Diolah)

Berdasarkan tabel diatas dapat dilihat bahwa nilai $R$ Square $\left(R^{2}\right)$ koefisien determinasi sebesar 0,955 atau sama dengan 95,5\% artinya perputaran kas, perputaran piutang, dan perputaran modal kerja dipengaruhi rentabilitas ekonomi sebesar 95,5\%. Sedangkan sisanya $4,5 \%$ dipengaruhi oleh variabel lain yang tidak masuk dalam penelitian ini seperti rasio likuiditas, solvabilitas.

\subsection{Pembahasan}

Berdasarkan hasil pengujian parsial dan serempak dapat dijelaskan sebagai berikut :

Hasil penelitian secara parsial yang diperoleh mengenai pengaruh perputaran kas terhadap rentabilitas ekonomi pada PT. Wijaya Karya (Persero) Tbk yang terdaftar di Bursa Efek Indonesia adalah variabel perputaran kas secara parsial tidak berpengaruh signifikan terhadap rentabilitas ekonomi pada PT. Wijaya Karya (Persero) Tbk.

Hasil penelitian yang diperoleh secara parsial mengenai pengaruh perputaran piutang terhadap rentabilitas ekonomi pada PT. Wijaya Karya (Persero) Tbk yang terdaftar di Bursa Efek Indonesia adalah variabel perputaran piutang secara parsial berpengaruh signifikan terhadap rentabilitas ekonomi pada PT. Wijaya Karya (Persero) Tbk.

Hasil penelitian yang diperoleh secara parsial mengenai pengaruh perputaran modal kerja terhadap rentabilitas ekonomi pada PT. Wijaya Karya (Persero) Tbk yang terdaftar di Bursa Efek Indonesia adalah variabel perputaran modal kerja secara parsial tidak berpengaruh signifikan terhadap rentabilitas ekonomi pada PT. Wijaya Karya (Persero) Tbk.

Hasil uji simultan (uji F) menunjukkan bahwa secara simultan (bersama-sama) variabel perputaran kas, perputaran piutang, dan perputaran modal kerja secara simultan berpengaruh signifikan terhadap rentabilitas ekonomi.

Berdasarkan uji koefisien determinasi dapat dilihat bahwa nilai $R$ Square $\left(\mathrm{R}^{2}\right)$ koefisien determinasi sebesar 0,955 atau sama dengan 95,5\%. Artinya perputaran kas, perputaran piutang, dan perputaran modal kerja dipengaruhi rentabilitas ekonomi sebesar 95,5\%, sedangkan sisanya $4,5 \%$ dipengaruhi oleh variabel lain yang tidak masuk dalam penelitian ini seperti rasio likuiditas dan solvabilitas

\section{KESIMPULAN}

Berdasarkan hasil penelitian maka peneliti memberikan simpulan sebagai berikut :

1. Perputaran kas secara parsial tidak berpengaruh signifikan terhadap rentabilitas ekonomi pada PT. Wijaya Karya (Persero) Tbk, karena thitung $<$ ttabel yaitu 1,890< 2,03452 dengan nilai signifikansi 0,068 yakni lebih besar dari 0,05.

2. Perputaran piutang secara parsial berpengaruh signifikan terhadap rentabilitas ekonomi pada PT. Wijaya Karya (Persero) Tbk, karena thitung $>$ tabel yaitu 14,072 > 2,03452 dengan nilai signifikansi 0,000 yakni lebih kecil dari 0,05 .

3. Perputaran modal kerja secara parsial tidak berpengaruh signifikan terhadap rentabilitas ekonomi pada PT. Wijaya Karya (Persero) Tbk, karena thitung $<$ ttabel yaitu $0,726<2,03452$ dengan nilai signifikansi 0,473 yakni lebih kecil dari 0,05 . 
4. Perputaran kas, perputaran piutang, dan perputaran modal kerja secara simultan berpengaruh signifikan terhadap rentabilitas ekonomi karena nilai $F_{\text {hitung }}$ sebesar 228,352 sedangkan $F_{\text {tabel }}$ sebesar 2,90 $(228,352>2,90)$ dengan nilai signifikan 0,000 yakni lebih kecil dari 0,05 .

\section{REFERENSI}

[1] D. Efriyenti, "Pengaruh Perputaran Kas, Perputaran Piutang dan Perputaran Modal Kerja terhadap Rentabilitas pada PT Pelayaran Sinar Mandiri Sejahtera Kota Batam," J. AKRAB JUARA, vol. 3, no. 3, pp. 72-86, 2018.

[2] K. V. Natalia, K. Raharjo, and A. Supriyanto, "Pengaruh Perputaran Modal Kerja, Perputaran Kas Perputaran Piutang Dan Perputaran Persediaan Terhadap Profitabilitas Perusahaan Manufaktur Yang Terdaftar Di BEI Tahun 2011-2015," J. IIm. Mhs. S1 Akunt. Univ. Pandanaran, vol. 38, no. 1, pp. 2-7, 2015.

[3] J. Maulana and A. Karim, "Pengaruh Perputaran Piutang Dan Perputaran Kas Terhadap Tingkat Likuiditas (Quick Ratio) Pada Perusahaan Konstuksi (Studi Kasus Pt Wijaya Karya Tbk)," L. J., vol. 1, no. 1, pp. 76-87, 2021, doi: 10.47491/landjournal.v1i1.596.

[4] Novita panca Rini, "Pengaruh Perputaran Modal Kerja, Perputaran Kas, Perputaran Piutang Dan Perputaran Persediaan Terhadap Profitabilitas Pada Industri Barang Komsumsi Yang Terdaftar Di Bursa Efek Indonesia," J. Ilm. Mhs. S1 Akunt. Univ. Pandanaran, vol. 1, no. 1, pp. 1-17, 2015.

[5] A. Eksandy and V. M. Dewi, "Pengaruh Perputaran Modal Kerja, Perputaran Piutang Dan Perputaran Kas Terhadap Profitabilitas Perusahaan ( Studi Pada Perusahaan Konstruksi Sektor Infrastruktur Di Bursa Efek Indonesia Periode 2012 - 2015 )," J. Din. UMT, vol. 2, no. 2, pp. 1-14, 2018.

[6] M. Mangantar, S. Nangoy, and I. Susanto, "Perputaran Modal Kerja terhadap Profitabilitas Perusahaan Asuransi yang Terdaftar di Bei," J. Ris. Ekon. Manajemen, Bisnis dan Akunt., vol. 2, no. 4, pp. 482-490, 2014.

[7] N. P. P. Wirasari and M. M. R. Sari, "Pengaruh Perputaran Modal Kerja, Perputaran Kas, Perputaran Piutang, Dan Pertumbuhan Koperasi Terhadap Profitabilitas," E-Jurnal Akunt. Univ. Udayana, vol. 17, no. 2, pp. 885-912, 2016.

[8] N. Sufiana and N. K. Purnawati, "Perputaran Persediaan Terhadap Profitabilitas," Fak. Ekon. Unud, pp. 451-468, 2013.

[9] D. Pratiwi, "Pengaruh Perputaran Modalkerja, Perputaran Piutang Dan Perputaran Persediaan Terhadap Profitabilitas Pada Perusahaan Industri Barang Konsumsi Di Bursa Efek Indonesia," J. IImu Manaj., vol. 7, no. 1, pp. 1-14, 2017, [Online]. Available: https://jurnal.um-palembang.ac.id/index.php/ilmu_manajemen/article/view/1022.

[10] Yusuf A. Muri, Metode Penelitian Kuantitatif, Kualitatif \& Penelitian Gabungan. Jakarta: Prenadamedia Group, 2014.

[11] N. Amos, Metode Penelitian dan Statistika. Bandung: PT Remaja Rosdakarya, 2014.

[12] Sugiyono, Metode Penelitian Kuantitatif, Kualitatif dan R\&D. Bandung: Alfabeta, 2017.

[13] G. Imam, Aplikasi Analisis Multivariate Dengan Program IBM SPSS. Semarang: Universitas Dlponegoro Press, 2018. 